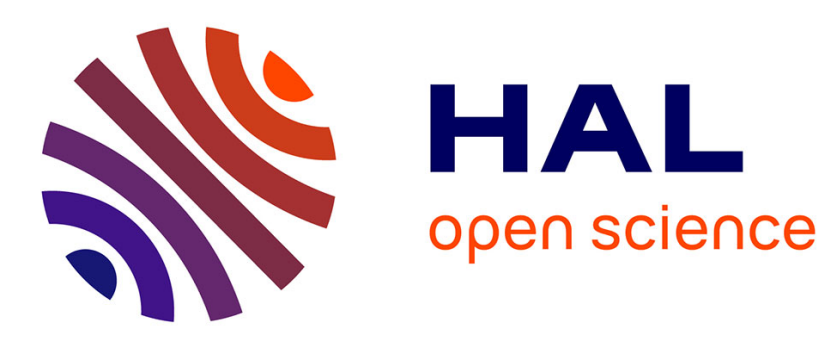

\title{
Transformational capacity in Australian peanut farmers for better climate adaptation
}

Nadine Marshall, Anne-Maree Dowd, Aysha Fleming, Clair Gambley, Mark Howden, Emma Jakku, Carl Larsen, Paul Marshall, Katie Moon, Sarah Park, et al.

\section{To cite this version:}

Nadine Marshall, Anne-Maree Dowd, Aysha Fleming, Clair Gambley, Mark Howden, et al.. Transformational capacity in Australian peanut farmers for better climate adaptation. Agronomy for Sustainable Development, 2014, 34 (3), pp.583-591. 10.1007/s13593-013-0186-1 . hal-01234807

\section{HAL Id: hal-01234807 \\ https://hal.science/hal-01234807}

Submitted on 27 Nov 2015

HAL is a multi-disciplinary open access archive for the deposit and dissemination of scientific research documents, whether they are published or not. The documents may come from teaching and research institutions in France or abroad, or from public or private research centers.
L'archive ouverte pluridisciplinaire HAL, est destinée au dépôt et à la diffusion de documents scientifiques de niveau recherche, publiés ou non, émanant des établissements d'enseignement et de recherche français ou étrangers, des laboratoires publics ou privés. 


\title{
Transformational capacity in Australian peanut farmers for better climate adaptation
}

\author{
Nadine Anne Marshall • Anne-Maree Dowd • Aysha Fleming • Clair Gambley • \\ Mark Howden • Emma Jakku • Carl Larsen • Paul Augustine Marshall • \\ Katie Moon • Sarah Park • Peter John Thorburn
}

Accepted: 20 September 2013 /Published online: 30 October 2013

(C) INRA and Springer-Verlag France 2013

\begin{abstract}
The food industry is vulnerable to climate change. Producers will need to adapt to climate change if they, and the communities dependent on them, are to remain viable. There are essentially two ways to adapt - incrementally and transformationally. We differentiate between incremental and transformative adaptation mostly on the basis of the size of the change needed. Here, we studied the Australian peanut
\end{abstract}

N. A. Marshall $(\square)$

CSIRO Ecosystem Sciences and Climate Adaptation Flagship,

ATSIP Building at James Cook University, Townsville, QLD 4811, Australia

e-mail: nadine.marshall@csiro.au

A.-M. Dowd

CSIRO Science into Society and Climate Adaptation Flagship,

Dutton, QLD 4001, Australia

\author{
A. Fleming \\ CSIRO Science into Society and Climate Adaptation Flagship, \\ Battery Point, Hobart, TAS 7001, Australia \\ C. Gambley $\cdot$ E. Jakku • P. J. Thorburn \\ CSIRO Ecosystem Sciences and Climate Adaptation Flagship, \\ Brisbane, QLD 4001, Australia \\ M. Howden $\cdot$ S. Park \\ CSIRO Ecosystem Sciences and Climate Adaptation Flagship, \\ Canberra, ACT 2601, Australia \\ C. Larsen \\ RM Consulting Group, Suite 1, 357 Camberwell Road, Camberwell, \\ VIC 3124, Australia

\section{P. A. Marshall} \\ Great Barrier Reef Marine Park Authority, Flinders St., Townsville, \\ QLD 4801, Australia \\ K. Moon \\ ANZSOG Institute for Governance and Institute of Applied Ecology, \\ University of Canberra, Bruce, ACT 2601, Australia
}

industry, which is already experiencing the effects of climate change. We expand on the notion of adaptive capacity and refer to 'transformational capacity' and test its association with resource dependency. Resource dependency is a measure of the interactions that primary producers have with a natural resource and includes factors such as occupational identity, networks, resource use as well as a range of financial factors. We hypothesized that some primary producers were more likely to demonstrate higher levels of transformational capacity if they possessed lower levels of resource dependency. We surveyed, by phone, 69 farmers representing $87 \%$ of the peanut industry in northern Australia. Our results show that the capacity to transform depends upon individual's networks, their employability, tendency for strategic thinking and planning, business profitability, local knowledge, environmental awareness, use of irrigation and use of climate technology. Barriers to transformational change were occupational identity, place attachment and dependents. Our study is one of the first to focus on transformational capacity. This approach allows us to understand why some individuals are better able to adapt to change than others and also to assist industry and community leaders to develop broad-scale strategies.

Keywords Adaptive capacity $\cdot$ Barriers to change $\cdot$ Natural resource management $\cdot$ Social resilience $\cdot$ Climate change adaptation $\cdot$ Social vulnerability $\cdot$ Resource dependency

\section{Introduction}

Climate change is unlike any other disturbance experienced by contemporary society; climate change can rapidly alter the quality and availability of natural resources and it has the potential to simultaneously and severely affect extensive areas of land and sea (IPCC 2007). Humans have the opportunity to 
affect the ultimate outcomes of climate change in two essential ways: mitigation and adaptation. By reducing global emissions of greenhouse gasses (mitigation), we can deal with the root cause of the problem and limit the magnitude of humaninduced global climate change (Howden et al. 2007). By building the capacity to adjust climate-sensitive activities to plausible future climate scenarios (adaptation), we can adapt and limit our vulnerability to the climate change that does occur (Adger 2006; Jones 2000; Marshall et al. 2012). The two processes are linked in that the more effort that is put into mitigation efforts, the less effort will be required for adapting. We focus on developing strategies to inform adaptation. Adaptation will make a major difference to the extent of the impacts of climate change. While strong arguments exist to stabilise greenhouse gas concentrations before the climate system passes irreversible thresholds, we can also accelerate efforts to prepare for those changes that are inevitable (Pielke et al. 2007; Stokes and Howden 2010).

Primary industries and enterprises, which include the sectors of agriculture, forestry and fisheries, are especially vulnerable to climate change because they are dependent on resources that are highly climate sensitive (Fleming and Vanclay 2010; Howden et al. 2007; Stokes and Howden 2010). Resource dependency can make resource users especially sensitive to changes that occur in the resource as a result of climate change (Marshall 2010; Vishnudas et al. 2008). However, while resource dependency (or sensitivity to change) may describe the likely impacts of climate change, adaptive capacity can be a major influence on what impacts actually eventuate (Marshall et al. 2012, 2013). Recognising and enhancing adaptive capacity becomes increasingly important for resource-dependent industries facing significant climate change (Kelkar et al. 2008).

Resource-dependent industries will need to adapt to significant climate changes in some regions of the world (IPCC 2007). In addition, current predictions of climate shifts suggest that implementing incremental changes in some regions may be insufficient for adaptation; resource users and the industries that define them may need to undergo changes in function or structure - and undergo transformational adaptation - if they are to remain viable (Park et al. 2012; Rickards and Howden 2012). For example, the impact of warming temperatures is already affecting the quantity and quality of wine grapes produced in southern Australia (Park et al. 2012). With projections for an ongoing increase in temperatures and potentially a reduction in rainfall in many regions in Australia (IPCC 2007), it is possible that in some wine grape-growing regions current varieties may become increasingly unviable. Subsequently, the industry is considering adaptation responses such as relocation, which are essentially transformational (Kates et al. 2012; Park et al. 2012). Yet, for such transformational change to be successful, the capacity to undertake such change will need to exist. Through ensuring that the capacity to adapt to a range of climate change events exists, resourcedependent industries can enhance their chances for successfully responding to climate change.

The distinction between incremental and transformational adaptation refers mostly to the 'size' of the change that is anticipated to occur (Kates et al. 2012). Moser and Ekstrom (2010) suggest that the capacity to cope and adapt to changes requiring incremental changes is not that different from needing to adapt to change requiring transformational changes: the distinction being across temporal, spatial, and social scales, where transformational change occurs at the long-term end of the adaptation spectrum whilst coping measures occur in the short term. In their analysis, they found that transformations typically require greater time and effort than shorter-term coping or adaptation measures. The capacity to adapt to change - regardless of whether the change is incremental or transformational-requires the capacity to convert existing resources (financial, natural, human, social and physical) into successful adaptation strategies (Adger 2000; Cinner et al. 2011). This capacity is enabled through learning, the flexibility to experiment and adopt novel solutions, and the ability to respond generally to a broad range of challenges (Levin et al. 1998). It refers to the ability of individuals or communities to adapt to adversity and stressful life events by 'reorganising' through networks or institutions that learn, store knowledge and experience and are creative, flexible and novel in their approach to problem solving (Gunderson and Holling 2002). Only limited research has been conducted to date that explores the relationship between transformational and incremental capacity to change. Without knowledge of transformational capacity, resource-dependent industries are potentially limited in their capacity to develop strategies to adapt to the broad range of climate change impacts that are expected to occur.

A key challenge for industries that choose, collectively and proactively, to adapt to changing climatic conditions will be to ensure that sufficient capacity exists across scales (e.g. across individuals, communities, regions and nations). We focus on the capacity to adapt to transformational changes at the individual scale because this scale is under-represented in climate adaptation science yet is critical to the process of climate adaptation. Adaptation at the individual scale is likely to influence adaptation processes at other scales (Adger et al. 2012). For example, individual characteristics may be important in determining the success of an industry-led initiative; such initiatives may depend on the support and capacity of individuals (Marshall et al. 2013). Individual resource users who have a higher capacity to incorporate transformational change into their working lives are more likely to effectively trade-off the costs between short-term efforts to undertake transformational change and their future limitations to be productive (Marshall et al. 2011). For these people, change will no longer be seen as a disturbance, but as a trigger for the reorganisation of resources, and for the renewal of the farm organisation and 
activities (Darnhofer et al. 2010). Individuals that possess this capacity will not only ensure their own ability to cope and adapt to the impacts of climate change, but will contribute towards the success of their industry in coping and adapting to climate change. However, not all primary producers will have the same capacity to transform (Grantham et al. 2010). Our research aimed to understand the factors at the individual scale that are associated with higher adaptive capacity.

We use an approach developed by Marshall et al. (2012) to characterise and assess the capacity to transform. This capacity is based on that of adaptive capacity and is useful for analysing adaptation processes more generally. The approach consists of four composite factors or dimensions that are understood to be necessary 'preconditions' for adaptation to occur: (a) the management of risk and uncertainty; (b) the level of skills in planning, learning and reorganising for change; (c) the level of financial and psychological flexibility to undertake change and (d) the level of interest in undertaking change. These dimensions closely resemble the key drivers of adaptive capacity at other scales (Adger 2006). In this study, we use the four dimensions as a starting basis from which to investigate the factors that might be important in influencing transformational capacity.

Many factors are likely to predispose or limit the capacity of primary producers to adapt (Olsson et al. 2006). Primary producers will also be limited by their own characteristics and circumstances. For example, factors representing resource dependency (such as occupational identity, place attachment, networks, business approach and business size) have been shown to be important influences on adaptive capacity (Marshall et al. 2007; Vishnudas et al. 2008). Resource dependency is a concept that represents the intricate relationship that resource users have with a natural resource. This relationship may also be important in influencing the extent to which people are able to undertake change of a transformational nature. Other work has suggested that place attachment and occupational identity are important influences on transformational capacity (Marshall et al. 2012). Resource dependency has been described elsewhere as including the following components: (1) occupational attachment, (2) place attachment and (3) family, as well as through a lack of (4) employability, (5) networks, (6) business approach, (7) financial buffer, (8) financial turnover, (9) local knowledge, (10) environmental awareness, (11) use of irrigation, (12) use of technology, (13) diversity of household income and (14) diversity of farming income (Freudenberg 1992; Marshall 2011). Here, we examine the extent to which factors representing resource dependency are associated with transformational capacity.

\subsection{Case study}

We present a case study of the peanut industry in Queensland, Australia, to examine the influence of resource dependency on farmers' capacity to adapt to transformational change. Queensland has been the traditional 'home' of peanut production in Australia over the past 100 years. Over the past 25 years or so, however, climate change has reduced the viability of production in the region by about $30 \%$ through temperature increases and a lower than average rainfall. The peanut industry is particularly watchful for climatic changes since peanuts exposed to high temperatures and end of season drought can accumulate highly carcinogenic and immune-suppressing aflatoxins (Chauhan et al. 2010). The costs associated with minimising aflatoxin contamination negatively affect the profitability of peanut production (Chauhan et al. 2010). The marked decline in peanut production during recent years and the associated increase in disease in water-stressed peanuts are forcing peanut farmers to diversify their cropping options to non-peanut crops, threatening the viability of the shelling and processing components of the industry in the region. If peanut production is to continue, and the investment in the industry is to remain secure, a viable source of peanuts must be supplied.

In an attempt to transform the industry, the largest peanut company in Australia purchased 11,700 ha of land near Katherine in the Northern Territory in 2007, some 3,000 km away from their main office in Kingaroy, Queensland (Fig. 1). The Northern Territory property promised suitable conditions for growing peanuts and a reasonable availability of water year-round irrigation (Fig. 2). One strategy that was considered by the industry leaders was to encourage farmers from Queensland to translocate to Katherine as a planned collective response to anticipated change. However, for this strategy to be feasible, it was important to build and support the capacity

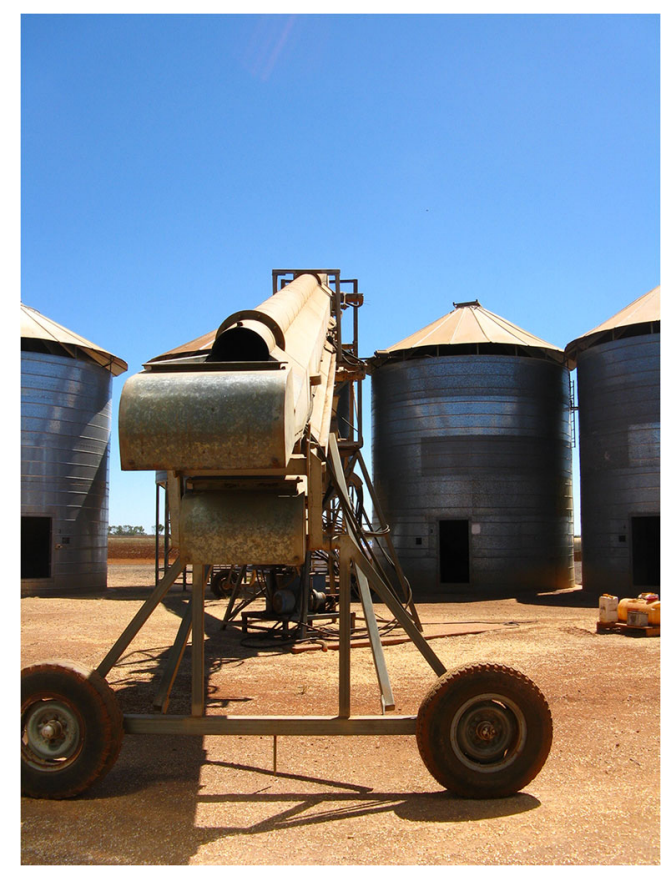

Fig. 1 Peanut storage facilities in Katherine, Northern Territory 


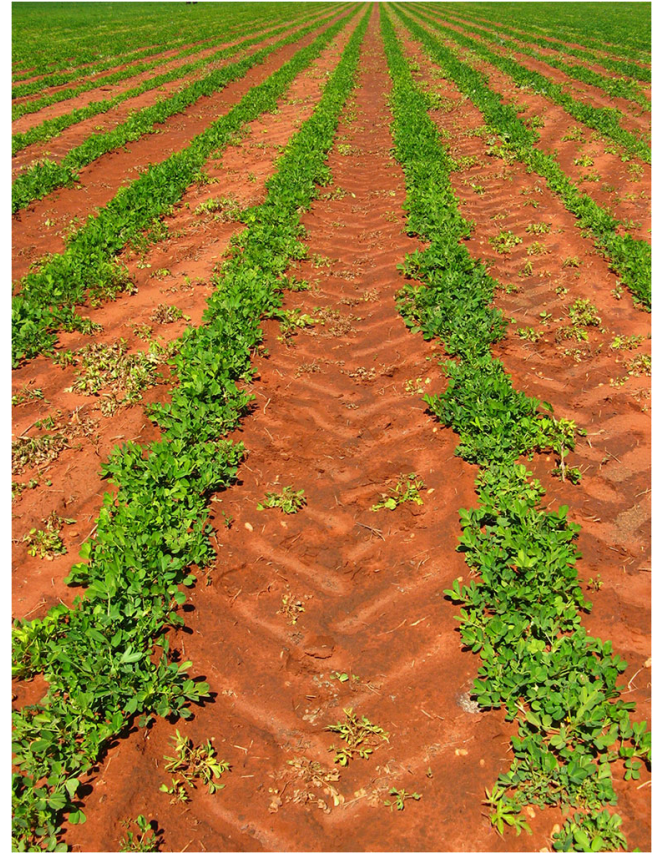

Fig. 2 Peanut crops in Katherine, Northern Territory

of peanut farmers to relocate to Katherine and continue growing peanuts. Eventually, in 2011, the strategy to relocate to Katherine was abandoned. In this study, we explored the relationship between existing capacity and resource dependency, and searched for lessons for other industries facing similar situations.

\section{Method}

\subsection{Survey development}

Survey questions were developed to quantify a peanut grower's capacity to change and their level of resource dependency as well as to describe the population (Marshall 2011). Most questions were presented as a statement designed to elicit an attitude, opinion or stance. Statements to assess transformational capacity (Marshall et al. 2012) and resource dependency (Marshall et al. 2007) were based on other studies. Respondents were asked to rate how strongly they agreed with each statement using a five-point rating scale. An initial version of the survey was pilot tested with five producers to ensure that the questions were readable and unambiguous. Ethics approval for the project was obtained from CSIRO, Ecosystem Sciences Human Ethics Committee (Project 019/10).

\subsection{Survey administration}

An intensive media campaign was undertaken to introduce the research to the region. Names, addresses, and telephone numbers of peanut growers were obtained from the industry in accordance with relevant ethical guidelines. All peanutgrowing families received a personal letter informing them of the research and inviting them to participate. Of the 90 names on the list, 79 households were contactable by telephone (others were presumed to already have left the industry). We asked if we could speak to the main 'decision-maker' within the family business. The project was again introduced to farmers and oral informed consent was provided by 69 people (all males), representing $87 \%$ of the industry. Interviews were conducted between June and October 2010 and took between 45 and 90 min.

\subsection{Survey analysis}

Descriptive statistics were used to portray the sample population of peanut farmers, their transformational capacity and their level of dependency on the resource. The 14 components of resource dependency and the four components of transformational capacity were assessed for each peanut producer by calculating an $F$ score or 'weighted mean' for the set of responses to relevant statements. $F$ scores range from 1 (perfect positive correlation) to -1 (perfect negative correlation) and a score of 0 indicates no linear statistical relationship. $F$ scores were calculated by conducting a factor analysis or principal components analyse in SPSS ${ }^{\circledR}$ and forcing the data into one factor only. This means that we assumed that the responses to the set of statements representing each dimension of resource dependency and transformational capacity were correlated. Correlations between adaptive capacity and resource dependency were analysed using Spearman correlation matrices on the basis of $F$ scores for each variable. The responses to statements about each component of resource dependency and adaptive capacity were forced into one respective principal component, and the $F$ scores saved. Descriptive statistics were used to present the adaptive capacity and level of climate sensitivity (resource dependency) of producers.

\section{Results and discussion}

Our results show that peanut producers can vary in their capacity to transform along several dimensions providing some insight into why some individuals might be better at adapting to change than others (Table 1). Whilst some individuals might have low levels of capacity on one or more dimensions, it is possible for two individuals to share low levels of capacity but for different reasons. That is, our results suggest that not all individuals have the same capacity to transform; some individuals are likely to face considerable barriers that make embarking on their own adaptation pathway too challenging. The complex nature of adaptive or transformational capacity suggests that any single initiative 
Table 1 The transformational capacity of peanut farmers in Queensland $(n=69)$. Transformational capacity is assessed according to four dimensions (A, B, C, D). The mean, standard error (SE) and mode of the responses to each statement within each dimension are presented. Results suggest that peanut farmers have a relatively high capacity to transform on all four dimensions (mean and mode results higher than 2.5 on a scale of $1-5$, or less than 2.5 for negatively worded statements). Standard errors suggest that not all farmers have equal capacity to transform

\begin{tabular}{|c|c|c|c|}
\hline & Mean (scale 1-5) & SE & Mode \\
\hline \multicolumn{4}{|l|}{ A. Perceptions of the risks associated with change } \\
\hline If the climate changes, there is much I can do to respond to the opportunities & 3.4 & 0.13 & 4 \\
\hline Climate change brings great opportunities & 2.45 & 0.15 & 2 \\
\hline I have many options available to me other than being a farmer & 3.17 & 0.15 & 4 \\
\hline The important thing for me is to minimise my losses during bad seasons & 4.02 & 0.13 & 4 \\
\hline \multicolumn{4}{|l|}{ B. The level of skills in planning, learning and reorganising } \\
\hline If there is a drought, I just hope for the best ${ }^{\mathrm{a}}$ & 2.42 & 0.16 & 1 \\
\hline $\begin{array}{l}\text { Current approaches for dealing with present climate challenges will be sufficient for dealing with future } \\
\text { climate challenges }^{\mathrm{a}}\end{array}$ & 2.86 & 0.27 & 4 \\
\hline I don't really believe in long-term planning — things are too uncertain ${ }^{\mathrm{a}}$ & 2.72 & 0.17 & 2 \\
\hline I like to experiment with new ways to farm & 4.01 & 0.14 & 4 \\
\hline \multicolumn{4}{|l|}{ C. The level of financial and emotional flexibility } \\
\hline Regardless of what happens, we have made sure that we are financially secure & 3.41 & 0.15 & 4 \\
\hline I am less likely to survive drought compared to other farmers I know ${ }^{a}$ & 2.04 & 0.11 & 2 \\
\hline If needed, I am prepared to completely change the way I manage my property in order to survive as a farmer & 3.73 & 0.14 & 4 \\
\hline \multicolumn{4}{|l|}{ D. The level of interest in undertaking change } \\
\hline Climate impacts are unlikely to manifest in this region for some time ${ }^{\mathrm{a}}$ & 2.91 & 0.15 & 4 \\
\hline I am interested in learning about climate change and its impacts on the peanut and farming industry & 3.39 & 0.14 & 4 \\
\hline I am interested in learning new skills & 3.86 & 0.14 & 4 \\
\hline
\end{tabular}

${ }^{a}$ Responses to these negative questions were reversed prior to analysis

led by the industry to enhance capacity is thus unlikely to be successful (Campbell et al. 2006). Yet, resource industries may wish to seriously consider enhancing the capacity of their industry members (such as farmers, fishers, foresters, graziers) to undergo transformation as a climate change response since the transformational success of the industry may depend on individuals being able to transform (Marshall et al. 2013). If so, a range of initiatives will be needed to enhance transformational capacity at the individual level to ensure the success of planned transformational changes at the industry level (Newsham and Thomas 2011).

Initiatives to enhance the transformational capacity of primary producers will need a novel approach. For example, results from Table 1 suggest that peanut producers were less likely to see the opportunities associated with climate change ("Climate change brings great opportunities" received a mean of 2.45 on a scale of 1-5), than they would see the need to minimise their losses during bad seasons ("The important thing for me is to minimise my losses during bad seasons" received a 4.02 on a scale of $1-5$ ). That is, peanut producers did not necessarily approach the risks associated with climate change uniformally. Results suggest that in order to enhance the capacity of peanut farmers on the first dimension of transformational capacity (the perceptions of the risks and the management of uncertainty) they would require assistance to see the opportunities associated with climate change, including the possibility of suitable alternative employment opportunities (Howden et al. 2007). Any intervention that assists primary producers to confidently approach risk and manage uncertainty, such as through facilitated or collaborative learning opportunities, is likely to be important. Drawing on learned experience from previous extreme weather events such as drought through discussion groups, and combining these with the strategic priorities of the farm business, provides legitimacy for how individuals readily adapt (Marshall et al. 2013).

The capacity of peanut producers on the second dimension was equally variable, but farmers were more aware of the need to be strategic. For example, farmers were generally negative to the sentiment that, "if there is a drought, I just hope for the best" (mean of 2.42 on a scale of 1-5). Similarly, farmers gave the impression that they were open to trying new ways to farm since they were generally positive to the statement, "I like to experiment with new ways to farm" (mean of 4.01 on a scale of 1-5). These results suggest that encouraging the development of skills for planning, learning and reorganising (the second dimension of transformational capacity), again through enhanced networking and collaborative learning opportunities, may be positively received and may enable producers to be more proactive during drought periods and to 
consider alternative approaches for dealing with future climate challenges (Marshall et al. 2011). Enhancing the capacity to transform on this dimension might occur through peer-to-peer learning and through social interaction in discussion groups. These strategies may assist individuals to make complex decisions, provide informal environments to explore scenarios and maintain and establish networks (Larsen et al. 2012). Building climate variability and change into general farm business risk management and planning approaches through discussions with trusted advisors and service providers can also be effective (McGuckian and Rickards 2011; Rickards et al. 2011).

Peanut producers appeared to have the necessary emotional and financial capacity to transform. For example, they responded negatively to the statement, "I am less likely to survive drought compared to other farmers I know" (mean of 2.04 on a scale of $1-5$ ). They responded positively to the statement, "if needed, I am prepared to completely change the way I manage my property in order to survive as a farmer" $($ mean $=3.73)$. In other contexts, perhaps, primary producers could be encouraged to increase their proximity from their thresholds of coping (the third dimension of transformational capacity) by supporting them during drought periods and assisting them to have a collaborative outlook that increases their drought knowledge and provides useful technical and emotional networks.

Peanut farmers also appeared to be interested in transforming if the need arose. For example, they responded positively to the statement, "I am interested in learning new skills" (mean=3.86), and responded positively to the statement, "I am interested in learning about climate change and its impacts on the peanut and farming industry" (mean=3.39). The fourth dimension of transformational capacity (the interest in change) could be improved or stimulated through providing primary producers with climate change information and knowledge, particularly pertaining to their region (where possible). Other research has suggested that the information must be appropriately framed, ensure regional and industry relevance and consider the needs of the target audience (Marshall et al. 2011)

Primary producers also varied from each other in their levels of dependency on the natural resource (Table 2). For example, some peanut producers in our study had experience outside of the industry (mean $=1.35$ on a scale of 2 where $1=$ yes and $2=$ no); fewer had a trade certificate or degree (mean= 1.60 on a scale of 2 where $1=$ yes and $2=$ no). Some farmers were highly supportive of statements such as, "I am unlikely to move elsewhere to farm if conditions become unsuitable here" (mean of 3.2 on a scale of 1-5) whereas many were not. One quarter of our sample suggested that if they could no longer be a farmer they would take an early retirement, but nearly $40 \%$ suggested that they would search for non-farm employment elsewhere. Some (mean=3.26) felt confident that they had strong formal or informal networks or in their approach to conducting business in the region (mean=3.16). Some peanut producers saw themselves as a "lifestyle" farmer (mean=3.71), whilst others saw themselves as businessoriented in their approach to their farm. There was high consensus among peanut producers in this study regarding occupational identity, whereby most individuals strongly identified with being a farmer (for example, "being a farmer is a lifestyle - it is not just my job" received a mean of 3.71 on a scale of 1-5 and, "farming is what I know best" received a mean of 4.11). They also felt that they were continually in touch with the condition of their land (the statement "I continually monitor the condition of my land so that I can recognise important changes" received a mean of 4.21), suggesting that they could respond to environmental feedbacks. However, farmers varied in their understanding of whether land condition was related to land management or the local environment, climate and geology ("land condition is not related to the way we use the land, but rather to the local environment, climate and geology" received a mean of 3.4; Table 2).

Our most significant finding related to the interaction between transformational capacity and resource dependency. In our endeavour to discover which peanut producers were most likely to transform and adapt to climate change, we found that peanut producers that were well-networked (Pearsson correlation $>0.260$ on three dimensions of transformational capacity), employable ( $\mathrm{Pc}=0.313$ on the second dimension of capacity), strategic ( $\mathrm{Pc}>0.283$ on three dimensions), profitable $(\mathrm{Pc}=0.376$ on the second dimension), had local knowledge $(\mathrm{Pc}=0.331$ on at least two dimensions), environmental awareness $(\mathrm{Pc}=0.407$ on at least two dimensions) and used irrigation $(\mathrm{Pc}=0.285$ on at least two dimensions) and technology $(\mathrm{Pc}=0.287$ on at least two dimensions) and had lower attachments to place $(\mathrm{Pc}=-0.252$ on the third dimension) and occupation $(\mathrm{Pc}=-0.270$ on the third dimension) were more likely to have a higher capacity (Table 3).

Producers that were poorly networked, unemployable, unstrategic, unprofitable, with little local knowledge or environmental awareness, did not use technology and had higher attachments to place and occupation exhibited lower levels of transformational capacity (Table 3). Not all of these interactions can be effectively managed within reasonable time frames (such as occupational identity or place attachment), but we see that many can. For example, climate adaptation strategies that focus on strengthening networks within an industry, developing strategic skills sets, encouraging the development of local knowledge and use of technology and irrigation are likely to be an important start. Whilst we do not want to imply causality, we see that incentives that encourage resource users to consider strategies along these lines may be important for stimulating better preparedness for the future. If industry leaders can encourage resource users to 
Table 2 Resource dependency of peanut farmers in Queensland $(n=69)$. Resource dependency is assessed according to 14 dimensions. Results suggest that peanut farmers have high dependency on the natural resource because of their occupational identity (mean of $>2.5$ on a scale of $1-5$ ), place attachment, employability (older, level of transferable skills), have dependents and lack of environmental awareness

\begin{tabular}{|c|c|c|c|}
\hline & Mean (scale 1-5) & $\mathrm{SE}$ & Mode \\
\hline \multicolumn{4}{|l|}{ 1. Identity } \\
\hline Farming is what I know best & 4.11 & 0.12 & 4.00 \\
\hline Being a farmer is a lifestyle - it is not just my job & 3.71 & 0.16 & 4.00 \\
\hline I would happily consider another occupation if the need arose & 2.84 & 0.15 & 4.00 \\
\hline \multicolumn{4}{|l|}{ 2. Place attachment } \\
\hline We would be willing to move elsewhere if things became too tough here & 2.55 & 0.15 & 2.00 \\
\hline I would never want to move from this region & 3.69 & 0.14 & 4.00 \\
\hline I am unlikely to move elsewhere to farm if conditions become unsuitable here & 3.20 & 0.75 & 4.00 \\
\hline \multicolumn{4}{|l|}{ 3. Employability } \\
\hline Year born in & 1959 & 1.25 & 1950 \\
\hline Have you completed a trade certificate or degree $(1=$ yes, $2=$ no $)$ & 1.6 & 0.05 & 2 \\
\hline Have you ever worked outside of the farming industry? $(1=$ yes, $2=$ no $)$ & 1.35 & 0.05 & 1 \\
\hline What would you do if you could no longer be a farmer? & $\begin{array}{l}\text { Farm job }=6 \% \\
\text { Retire }=25 \% \\
\text { Don't know }=31 \% \\
\text { Non-farm }=38.2 \%\end{array}$ & & \\
\hline \multicolumn{4}{|l|}{ 4. Family member } \\
\hline How many dependents do you have? $<16$ years olds & 1.07 & 0.16 & 0 \\
\hline \multicolumn{4}{|l|}{ 5. Networks informal } \\
\hline I discuss approaches for dealing with climate challenges with other farmers & 3.26 & 0.14 & 4 \\
\hline \multicolumn{4}{|l|}{ 6. Networks formal } \\
\hline I like to discuss approaches for dealing with climate challenges with government agencies and researchers & 3.18 & 0.15 & 4 \\
\hline I have good networks to access government agencies and government assistance & 3.18 & 0.16 & 4 \\
\hline \multicolumn{4}{|l|}{ 7. Business approach } \\
\hline I always access expertise before I make an important business decision & 3.53 & 0.15 & 4 \\
\hline I always know how much money comes in and out of my business each month & 3.65 & 0.15 & 4 \\
\hline I am more of a "lifestyle" farmer and focus less on making a profit" & 3.8 & 0.15 & 5 \\
\hline \multicolumn{4}{|l|}{ 8. Financial buffer } \\
\hline On a scale of $1-5$, would you say you have a strong financial buffer in case of emergencies? & 3.5 & 0.17 & 5 \\
\hline \multicolumn{4}{|l|}{ 9. Financial turnover } \\
\hline Approximately, how much income does your business produce (turnover) each year? & 2.44 & 0.13 & 2 \\
\hline Approximately, how much income does your business produce from peanuts? & 1.43 & 0.08 & 1 \\
\hline \multicolumn{4}{|l|}{ 10. Local knowledge } \\
\hline I continually monitor the condition of my land so that I can recognise important changes & 4.21 & 0.08 & 4 \\
\hline I have the skills or knowledge to protect my land from drought & 3.36 & 0.15 & 4 \\
\hline \multicolumn{4}{|l|}{ 11. Environmental awareness } \\
\hline $\begin{array}{l}\text { Land condition is not related to the way we use the land, but rather to the local environment, climate } \\
\text { and geology } \\
\text { 12. Use of irrigation }\end{array}$ & 3.4 & 0.13 & 3 \\
\hline Do you irrigate your crops? $(1=$ yes, $2=$ no $)$ & 1.2 & 0.05 & 1 \\
\hline What has been your water allocation for the past 5 years? & 1,115 & 548 & 0 \\
\hline \multicolumn{4}{|l|}{ 13. Use of technology } \\
\hline I am very keen to access scientific technology and expertise relating to the climate & 3.65 & 0.13 & 4 \\
\hline I use what climate technology I can access such as forecasting tools & 3.68 & 0.12 & 4 \\
\hline \multicolumn{4}{|l|}{ 14. Production levels } \\
\hline Approximately, how many tonnes of peanuts do you currently produce? & 205 & 31 & 0 \\
\hline
\end{tabular}

${ }^{\mathrm{a}}$ Responses to these negative questions were reversed prior to analysis 
Table 3 The level of association between resource dependency and adaptive capacity. Results of a Spearman correlation matrix between social, economic, environmental and technical aspects of resource dependency, and the four dimensions of transformational capacity (risk management, planning, coping and interest).

Results suggest that peanut farmers that have the highest level of transformational capacity also have a relatively high level of formal and informal networks, a strategic business approach, a high level of financial turnover, high environmental awareness and local knowledge, irrigate and use climate technology
${ }^{*} p<0.05$, indicates a significant influence; ${ }^{* *} p<0.01$, a highly significant influence

\begin{tabular}{lllll}
\hline Transformational capacity & Risk & Planning & Coping & Interest \\
\hline Social aspects & & & & \\
$\quad$ Identity & 0.057 & -0.208 & 0.199 & $-0.270^{*}$ \\
Place attachment & -0.042 & -0.190 & 0.226 & $-0.252^{*}$ \\
Employability & -0.118 & $-0.313^{*}$ & 0.210 & -0.211 \\
Family members & 0.150 & 0.069 & $-0.248^{*}$ & -0.107 \\
Networks informal & $0.280^{*}$ & $0.328^{* *}$ & $0.268^{*}$ & 0.197 \\
Networks formal & $0.280^{*}$ & $0.328^{* *}$ & $0.268^{*}$ & 0.197 \\
Economic aspects & & & & \\
Business approach & $0.659^{* *}$ & 0.213 & $0.283^{*}$ & $0.328^{* *}$ \\
Percent of income from peanuts (farm diversity) & -0.148 & -0.188 & -0.124 & -0.066 \\
Percent of income from farming & -0.024 & 0.091 & 0.038 & -0.180 \\
Business size & 0.067 & 0.138 & -0.008 & -0.025 \\
Financial buffer & 0.198 & 0.107 & $0.412^{* *}$ & 0.023 \\
Financial turnover & 0.139 & $0.376^{* *}$ & 0.055 & 0.170 \\
Environmental aspects & & & & \\
Local knowledge & $0.331^{* *}$ & $0.474 * *$ & 0.131 & 0.088 \\
Environmental awareness & $0.563^{* *}$ & $0.407^{* *}$ & -0.064 & 0.150 \\
Resource use & 0.070 & $0.628^{* *}$ & 0.172 & $0.285^{*}$ \\
Technical aspects & & & & $0.391^{* *}$ \\
Use of technology & $0.578^{* *}$ & $0.287^{*}$ & 0.026 & 0.149 \\
Production levels & -0.019 & $0.374^{* *}$ & 0.008 & \\
\hline
\end{tabular}

develop their capacity to adapt and transform, then the success with which resource industries can respond to the impacts of climate change in their region is likely to be positively influenced.

Governments, communities and other institutions that support primary industries must play a vital role in assisting resource industries to develop the capacity to undertake a range of adaptations (Park et al. 2012). To date, the significant social challenges associated with adapting to climate change have not been well incorporated into climate adaptation planning processes and this outcome presents risks that the adaptation process will not bring net benefits (Adger et al. 2011; Adger et al. 2012). Our results suggest that strategies to enhance adaptive capacity need to be more innovative than simply providing fiscal resources. For example, we did not find that income diversity at the farm or household levels were significantly correlated with transformational capacity. Providing financial resources to primary producers is unlikely to enhance their capacity to transform. Focusing investments on those factors known to be associated with capacity are more likely to be effective.

Creating supportive policy environments that enable lower-risk change pathways and that provide well-matched incentives for effective change will be important (Paavola and Adger 2006). Future research might identify and test the significance of other influences on transformational capacity. For example, how people embedded within different institutional contexts are enhanced or restricted in their capacity may be important for learning across scales. In the meanwhile, our results from producers within the Australian peanut industry provides some evidence that the capacity to transform is positively associated with the extent of an individual's networks, their employability, tendency for strategic thinking and planning, business profitability, local knowledge, environmental awareness, use of irrigation and use of climate technology. This knowledge may significantly assist industry and community leaders to develop broad-scale strategies that assist industry members to adopt industry-led strategies and adapt.

\section{Conclusion}

In this study, we show how concepts such as transformational capacity can be assessed and quantified at the scale of the primary producer so as to identify the likelihood that transformation might occur not only at this scale, but at other scales. In the case of the peanut-producing industry of northern Australia, we see that some individuals are more likely to undertake transformational change than others. These individuals were more likely to be well-networked, employable, strategic, profitable, have local knowledge, be environmentally aware and use irrigation and technology. They were also likely to have a lower attachment to place and occupation. 
These findings may be important for industry leaders wishing to enhance the capacity of their constituent members to undertake transformational change.

We conclude that if climate adaptation and the adoption of transformational strategies are to be successful, investing in the capacity of resource users to change may be important. Strategies to consider include assisting individuals to develop their networks, increase their employability, develop their strategic thinking and planning skills, plan for business profitability, invest in local knowledge, develop an environmental awareness, use irrigation and use climate technology.

Acknowledgments The authors are sincerely grateful to the 69 farmers who agreed to participate in the study and to Rebecca Vallis who interviewed them. We would like to acknowledge the support of the CSIRO Climate Adaptation Flagship and the Department of Agriculture, Forests and Fisheries, Australia.

\section{References}

Adger WN (2000) Social and ecological resilience: are they related? Prog Hum Geogr 24:347-364

Adger WN (2006) Vulnerability. Glob Environ Chang 16:268-281

Adger WN, Barnett J, Chapin FS, Ellemor H (2011) This must be the place: underrepresentation of identity and meaning in climate change decision-making. Glob Environ Polit 11(2):1

Adger WN, Brown K, Barnett J, Marshall NA, O'Brien K (2012) Cultural dimensions of climate change impacts and adaptation. Nat Clim Chang 3:112-117

Campbell BM, Gordon IJ, Luckert MK, Petheram L, Vetter S (2006) In search of optimal stocking regimes in semi-arid grazing lands: one size does not fit all. Ecol Econ 60:75-85

Chauhan YS, Wright GC, Rachaputi N, Holzworth DP, Broome A, Krosch S, Robertson MJ (2010) Application of a model to assess aflatoxin risk in peanuts. J Agric Sci 148:341-351

Cinner JE, Folke C, Daw T, Hicks CC (2011) Responding to change: using scenarios to understand how socioeconomic factors may influence amplifying or dampening exploitation feedbacks among Tanzanian fishers. Glob Environ Chang 21(1):7-12

Darnhofer I, Bellon S, Dedieu B, Milestad R (2010) Adaptiveness to enhance the sustainability of farming systems. A review. Agron Sustain Dev 30(3):545-555

Fleming A, Vanclay F (2010) Farmer responses to climate change and sustainable agriculture. A review. Agron Sustain Dev 30(1):11-19

Freudenberg WR (1992) Addictive economies: extractive industries and vulnerable localities in a changing world economy. Rural Sociol 57: 305-332

Grantham HS, Bode M, McDonald-Madden E, Game ET, Knight AT, Possingham HP (2010) Effective conservation planning requires learning and adaptation. Front Ecol Environ 8(8):431-437

Gunderson L, Holling CS (2002) Panarchy: understanding transformations in human and natural systems. Island Press, Washington

Howden SM, Soussana J, Tubiello FN, Chhetri N, Dunlop M, Meinke H (2007) Adapting agriculture to climate change. Proc Natl Acad Sci 104:19691-19696

IPCC (2007) Climate change 2007- the physical science basis - contribution of Working Group I to the Fourth Assessment Report of the International Panel on Climate Change. Cambridge University Press, Cambridge
Jones RN (2000) Analysing the risk of climate change using an irrigation demand model. Clim Res 14(2):89-100. doi:10.3354/Cr014089

Kates RW, Travis WR, Wilbanks TJ (2012) Transformational adaptation when incremental adaptations to climate change are insufficient. Proc Natl Acad Sci 109:7156-7161

Kelkar U, Narula KK, Sharma VP, Chandna U (2008) Vulnerability and adaptation to climate variability and water stress in Uttarakhand State, India. Glob Environ Chang 18:564-574

Larsen C, Boland A-M, Holland-Clift S, Anderson G. Working with service providers to improve climate and emissions services to farm businesses. In: Climate Change Research Strategy for Primary Industries Conference Proceedings, Melbourne. 27-29 November 2012

Levin S, Barrett S, Aniyar S, Baumol W, Bliss C, Bolin B, Dasgupta P, Ehrich PR, Folke C, Gren I, Holling CS, Jansson A, Jansson B, Maler K, Martin D, Perrings C, Sheshinski E (1998) Resilience in natural and socioeconomic systems. Environ Dev Econ 3:222-235

Marshall NA (2010) Understanding social resilience to climate variability in primary enterprises and industries. Glob Environ Chang 20(1): $36-43$

Marshall NA (2011) Assessing resource dependency on the rangelands as a measure of climate sensitivity. Soc Nat Resour 24(10):1105-1115

Marshall NA, Fenton DM, Marshall PA, Sutton S (2007) How resourcedependency can influence social resilience within a primary resource industry. Rural Sociol 72:359-390

Marshall NA, Gordon IJ, Ash AJ (2011) The reluctance of resource-users to adopt seasonal climate forecasts that can enhance their resilience to climate variability. Clim Chang 107(3):511-529. doi:10.1007/ s10584-010-9962-y

Marshall NA, Park SE, Adger WN, Brown K, Howden SM (2012) Transformational capacity and the influence of place and identity. Environ Res Lett 7(3):034022

Marshall NA, Tobin RC, Gooch M, Hobday A, Marshall PA (2013) Social vulnerability of marine resource users to extreme weather events. Ecosystems. doi:10.1007/s10021-10013-19651-10026

McGuckian N, Rickards L (2011) The social dimensions of mixed farming systems: decision making, drought and implications for extension. In: Tow PG, Cooper IM, Partridge I, Birch CJ (eds) Rainfed farming systems. Springer, Dordrecht, pp 805-821

Moser SC, Ekstrom JA (2010) A framework to diagnose barriers to climate change adaptation. Proc Natl Acad Sci 107(51):2202622031

Newsham AJ, Thomas DSG (2011) Knowing, farming and climate change adaptation in North-Central Namibia. Glob Environ Chang 21(2):761-770. doi:10.1016/j.gloenvcha.2010.12.003

Olsson P, Gunderson LH, Carpenter SR, Ryan P, Lebel L, Folke C, Holling CS (2006) Shooting the rapids: navigating transitions to adaptive governance of social-ecological systems. Ecol Soc 11(1):18

Paavola J, Adger WN (2006) Fair adaptation to climate change. Ecol Econ 56(4):594-609

Park SE, Marshall NA, Jakku E, Dowd AM, Howden SM, Mendham E, Fleming A (2012) Informing adaptation responses to climate change through theories of transformation. Glob Environ Chang 22(1):115-126

Pielke R, Prins G, Rayner S, Sarewitz D (2007) Climate change 2007: lifting the taboo on adaptation. Nature 445(7128):597-598

Rickards L, Howden SM (2012) Transformational adaptation: agriculture and climate change. Crop Pasture Sci 63(3):240-250

Rickards L, Hayman P, Eckard R. Lead paper. Agricultural adaptation to climate change: acknowledging different frames. Paper presented at the 5th World Congress of Conservation Agriculture, Brisbane, September 2011

Stokes CJ, Howden SM (2010) Adapting agriculture to climate change: preparing Australian agriculture, forestry and fisheries for the future. CSIRO, Canberra

Vishnudas S, Savenije HHG, van der Zaag P, Anil KR, Balan K (2008) Participatory research using coir geotextiles in watershed management- a case study in south India. Phys Chem Earth 33(1-2):41-47 